Verdes D. ${ }^{1}$, Boswell L. F. ${ }^{2}$

${ }^{1}$ Technical University of Cluj-Napoca, Cluj-Napoca, Romania,

${ }^{2}$ City, University of London, London, UK,

E-mail:2l.f.boswell@city.ac.uk

\title{
THE APPLICATION OF STRUCTURAL MODELS AS A TEACHING TOOL FOR STUDENTS
}

\begin{abstract}
The use of simple experiments to demonstrate structural actions is an excellent way to understand structural actions that may be taking place in a real full scale structure. Of special interest is the problem of earthquake loading, which, because of its wide spread nature and potentially damaging effects has assumed a greater importance in our highly urban society. The work, that is described in this paper, is part of the Civil Engineering undergraduate programme at the Technical University of Cluj-Napoca. It is a very successful experimental programme involving a group of students who entered an international competition.
\end{abstract}

Keywords: experiments, structural models, earthquake loading, undergraduate programme, student competitions.

Вердес Д. ${ }^{1}$, Бозвелл Л. Ф. ${ }^{2}$

${ }^{1}$ Технический университет,

Клуж-Напока, Румыния,

${ }^{2}$ Сити, Лондонский университет,

Лондон, Великобритания,

E-mail: ${ }^{2}$ l.f.boswell@city.ac.uk

\section{ПРИМЕНЕНИЕ МОДЕЛЕЙ КОНСТРУКЦИЙ КАК ИНСТРУМЕНТ ОБУЧЕНИЯ СТУДЕНТОВ}

Аннотация. Применение простых экспериментальных моделей в учебном процессе позволяет наглядно показать и оценить влияние различных воздействий на реальные конструкции. Большое значение имеет изучение сейсмических воздействий, характеризующихся возможными обрушениями конструкций, особенно в связи с увеличивающейся сейсмической активностью. Материал этой статьи является частью программы бакалавриата по гражданскому строительству в Техническом университете г. Клуж-Напока (Румыния). Экспериментальная программа, описанная в статье, оказалась очень успешной, а студенты приняли участие в международном конкурсе. В процессе конкурса команда студентов разрабатывала проект многоэтажного здания, оценивала его сейсмическую прочность, строила модель здания и ее испытывала.

Ключевые слова: эксперименты, модели конструкций, сейсмические воздействия, программа бакалавриата, студенческие конкурсы.

(C) Verdes D., Boswell L. F., 2018

\section{Introduction}

The use of simple experiments to demonstrate structural actions is an excellent way to understand structural actions that may be taking place in a real full scale structure. Some actions such as tension and compression are easy to understand, while others, such as thin wall structure distortion or interactive three dimensional effects can be difficult to visualize. This paper considers the role of structural modelling to understand the behaviour of structures subjected to dynamic loading, particularly earthquake forces.

Dynamic modelling of structures is important in education, research and design [1]. In education, simple experiments demonstrate basic concepts of vibration to undergraduate and postgraduate students. In the area of structural research the small scale dynamic model has proved to be a powerful tool in extending knowledge and understanding in many complex situations where analytical techniques are inadequate. Also, a carefully constructed model aids the design of many dynamically loaded structures.

Of special interest is the problem of earthquake loading, which, because of its wide spread nature and potentially damaging effects has assumed a greater importance in our highly urban society.

The work that is described in this paper is part of the Civil Engineering undergraduate programme at the 
Technical University of Cluj-Napoca. It is a very successful experimental programme involving a group of students who entered an international competition. Many attributes were required from the students to produce a successful result. The work has demonstrated that studying can also be fun.

\section{The Examples and Design Competition}

The background of the experimental tests has been conducted at TU Cluj in the frame of a teaching activity by testing the models of structural elements and resistance structures. The samples of structural elements are made in plain concrete, reinforced concrete and steel and are undertaken at bachelor level. The samples for resistance structures are the subject of extra-curricular projects. The students involved in these activities are expected to have creative and initiative skills together the ability to communicate and innovate [2].

The overview of extracurricular projects includes the structural tests on the model and it relates to several projects presented in student competitions. We can mention the subjects concerning the Spaghetti Bridge, the High Rise Building Models designed for seismic resistance, etc. The students were encouraged to work in the project Seismic Design and attend the competition due to the fact that the Romania has high seismicity territory and also due to the skills and competences acquired by the students.

The Objectives and Key Elements of Working on The Project Seismic Design

The objectives are: to promote the study of Seismic Engineering among undergraduate students, provide civil engineering undergraduate students with an opportunity to work on a hands on project designing and constructing a cost effective frame building to resist seismic loading.

The study of Seismic Engineering at undergraduate level may be limited to the knowledge and understanding of the earthquake mechanism and the territory's seismicity, seismic response of buildings, underlying criteria for earthquake resistant design and new systems for seismic protection of buildings. Working for the model of a seismic resistant building provides an opportunity for undergraduate students to gain and accumulate knowledge and skills pertinent to the evaluation of seismic response of structures with simple configurations and structural systems such as moment resistant frames and shear walls at the least [2].

The students are encouraged to think about structural actions in terms of flow of forces and performance of the entire structure at the global and local member levels. The foremost of all the objectives in terms of technical competence is the exposure to the concept of structural dynamics and earthquake engineering, which are parts of the graduate curriculum. More than systematic study the students work effectively with the seismic ground motions and response spectrum, they could be innovative by designing the structural system understanding the problem of horizontal and vertical stiffness of the structure and the way to control the seismic energy dissipation system.

\section{The Requirements for The Seismic Design Project}

The students team has to: design a multi-story commercial office building, verify the seismic load resistance system, construct a scaled model from a balsa wood frame structure (scale 1/72), which was tested on a shake table during the event.

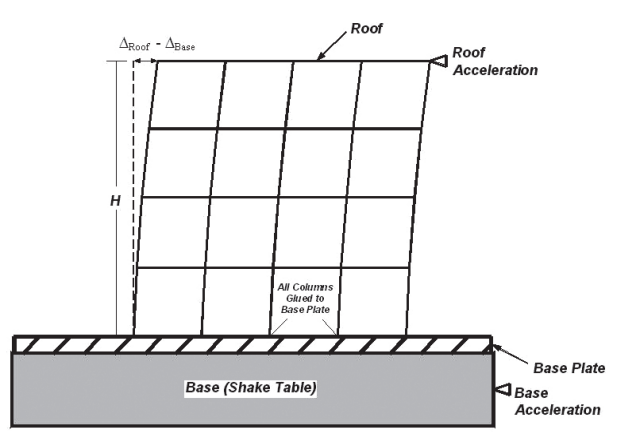

Fig. 1. The position of the accelerometers to measure the accelerations



Fig. 2. Type of experiments and accelerograms 
The model of 29th stories is subjected to severe ground motion excitations available online in the competition website. The seismic response of the structure was computed using time histories and response spectrums. The seismic performance of the structure was evaluated as the response predictions in terms of roof accelerations and drifts together with anticipated failure modes.

The horizontal acceleration was measured in the direction of shaking using accelerometers mounted on the roof of the structure and on the shaking table.

The Seismic Design Project gives the students the opportunity to acquire the outcomes for Earthquake Engineering at high level of cognitive achievement asked by the international standards of accreditations for the "First cycle" graduates conforming EURACE [3] respectively bachelor's degree conforming the BOK [4].

The students make the models conforming to the requirements of the project and attend the contest at TU Cluj in the frame of Seismic Engineering Centre. The project with the best result attends an international contest which is held in frame of Seismic Design Competition. The Seismic Design Competition (SDC) has taken place since 2004 in conjunction with the Earthquake Engineering Research (EERI) Institute (http://www. eeri.org), Annual Meeting; it is organized and conducted by The Student Leadership Council (SLC) of EERI from the USA (http://slc.eeri.org/seismic.htm).

The SDC is a two day event comprising of several events. It begins with the teams giving short presentations about various aspects of their design, analysis predictions and unique aspects of their as-built structure including innovativeness. It continues with poster presentations highlighting yet again the significant contributions and important aspects of the structures constructed including details about the flow of forces, anticipated performance in terms of roof accelerations and drifts and some of the major constructability issues. The teams also come up with estimates for construction cost and revenue generated in terms of rentable space. The hallmark of the event involves testing of the structures to typically 2 or 3 ground motions, modified to push the structure to significant non-linear limits.

\section{Outcomes of The Seismic Design Project}

The outcomes acquired are: Experiment, Design, Project management, Communications, Globalization, Leadership and Teamwork [1].



Fig. 3. Details of the model 29 stories: $a$ - cross section; $b-$ detailed view of cross section

The "Experiment" outcome is acquired at level L4: the students are familiar with purpose, procedures, equipment, and practical applications in the field of Earthquake engineering.



Fig. 4. Innovative damping systems designed by the team attending the $2011 \mathrm{SDC}$ 




Fig. 5. The model of balsa wood on the shake table before testing

The students are able to conduct the experiments, report results, and analyze results in accordance with the applicable standards and across more than one technical area as architecture and socio-economical aspects. The students made reports with the results of laboratory studies, virtual experiments, and numerical simulations; they gained the ability to conduct the experiment, analyze and explain the resulting data. The outcome "experiment" is fulfilled by some participants at Master level due to the good synthesis of the results.

The outcome "Design" is accomplished at level L6 including analysis and synthesis for the activities of designing, predicting performance, building, testing and fostering creative knowledge of students.

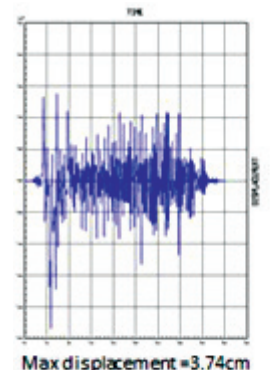

$=1.47$ in

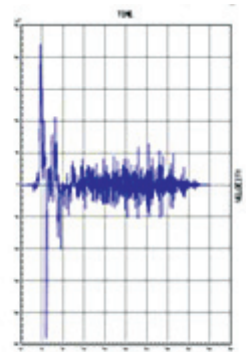

Maxvelocity $=3.36 \mathrm{~m} / \mathrm{s}$



Max acc $=2.02 \mathrm{~m} / \mathrm{s}^{\wedge} 2$ $=4.36 \mathrm{ft} / \mathrm{s}^{\wedge} 2$
Fig. 6. Results of seismic response of the model for the accelerogram GM3 and $15 \%$ damping:

from left to right: displacement, velocity, acceleration

The "Project management" is accomplished at level 4: the SDC project is an undergraduate research in the frame of an extracurricular project; the students had accomplished the activities: initiate, plan, execute, monitor and control, and close the project.

The outcome "Communication" is also acquired by students at level L5, including synthesis; the students created graphics to explain the complex systems and processes of their technical solution, a documented report, and made team presentations. The students prepared summaries of the work on posters and had conversations with technical audiences during the poster session. The outcomes "Leadership" and "Teamwork" are achieved by the students at L2 (comprehension) cognitive level and the "Globalization" is acquired at level 3, Application, in the context of theme "Earthquakes without Borders" and international ambiance of the event.



Fig. 7. The shapes of model from balsa wood constructed by teams from TU Cluj, attending the competition during 2011-2017 [6] 


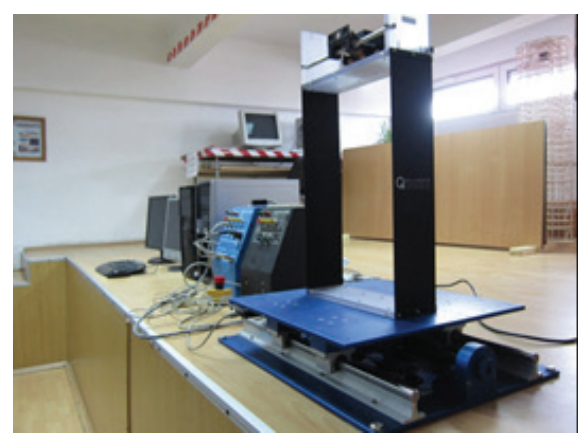

$a$

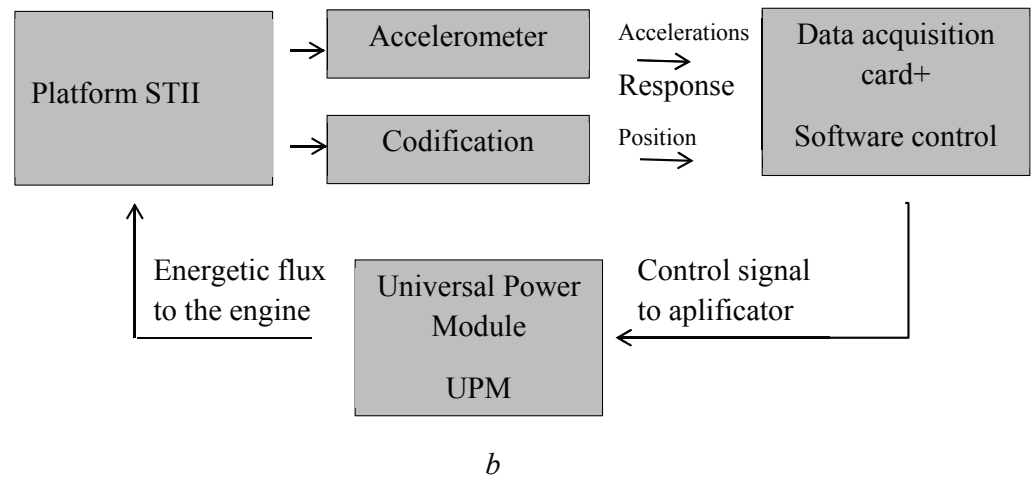

Fig. 8. The shake table at the laboratory of Seismic Engineering of Technical University of Cluj-Napoca: $a$ - the shake table STII; $b$ - the working diagram of the assembly STII

\section{Conclusion}

Apart from imparting technical knowledge in the areas of earthquake engineering and structural engineering in general, the activity of students in the frame of Seismic Design Project, offers a wide array of benefits in the form of personality development, project management and great professional exposure, at the least. Several such programs must be designed and conducted at the regional and international level to steer the young minds in the right direction to build a sustainable future.

\section{References}

1. Boswell L. F., Pantazidou M., Verdes D., Le Tallec B. Implementation of the framework for qualifications of a civil engineer based on learning outcomes and competences. In: Manoliu I. (ed.) Inquiries Into European Higher Education In Civil Engineering. Erasmus Thematic Network: European University Civil Engineering Education and Training (EUCEET), 2010, vol. 8, pp. 67-105.
2. Verdes D., Ramanathan K., Khosravifar A. The Role Of EERI Seismic Design Competition In Imparting Technical Competence And Professional Exposure In The Undergraduate Civil Engineering Curriculum. EUCEET Conference Proceedings. Greece, Patras, 2011.

3. European Accreditation of Engineering Programs (EURACE) (2008), EUR-ACE Framework standards for the accreditation of engineering programs. Available at: http://www.enaee. eu/the-eur-ace-system/eur-ace-framework-standards/**

4. Civil Engineering Body of Knowledge for the 21st Century: Preparing the Civil Engineer for the Future. Available at: http://www.asce.org/uploadedFiles/Leadership_Training New/BOK2E_\%28ASCE_2008\%29_ebook.pdf

5. Technical University of Cluj-Napoca, Faculty of Civil Engineering: Undergraduate Contests. Available at: https://constructii.utcluj.ro/concursuri-studentesti.html

6. The official page of the Seismic Design Competition Team of Technical University of Cluj-Napoca. Available at: https://www. facebook.com/utcnsdc 